\title{
David Oliver: When "resilience" becomes a dirty word
}

\author{
David Oliver consultant in geriatrics and acute general medicine
}

Berkshire

We need to talk about "resilience." One dictionary definition is "the capacity to recover quickly from difficulties; toughness." Health Education England describes it as "the ability to bounce back-a capacity to absorb negative conditions, integrate them in meaningful ways, and move forward." ${ }^{2}$ The General Medical Council announced in recent years that doctors under investigation and all medical students would receive "emotional resilience" training. ${ }^{34}$

Practising medicine has never been straightforward, and it has always required such attributes. Doctors carry responsibility, risk, uncertainty, and self doubt. We make difficult decisions and witness harrowing scenarios weekly-that's the nature of being a doctor. And, being human, it can get to us. Support to adapt and learn from these inherent challenges, and to develop coping skills, would be welcome in any health system.

But "absorbing" any unacceptably and avoidably "negative conditions"' makes resilience a dirty word. It shifts the blame and responsibility for doctors' struggles away from what are often over-politicised, understaffed, underfunded, badly organised systems and onto individuals.

"Absorbing negative conditions" shifts the blame for doctors' struggles away from over-politicised, understaffed, underfunded systems and onto individuals

Physician burnout is well reported in the United Kingdom and internationally. ${ }^{5}$ A recent survey of 3695 doctors who had graduated from UK medical schools in 1974 and 1979 found that $44 \%$ reported adverse effects of the job on their health and wellbeing. ${ }^{6}$ As the Royal College of Physicians' recent report Being a Junior Doctor showed, ${ }^{7}$ younger doctors will find the factors cited in the survey eerily familiar: long hours, excessive workload, poor work-life balance, compassion burnout, and managerial and regulatory changes are all there. As is the impact of doctors' own ageing and the failure of their roles and work patterns to adapt. ${ }^{8}$

There's nothing wrong with helping doctors build "resilience," if we must use the word. Mentorship, access to good occupational health, and counselling — such as the new GP health service ${ }^{9}$ - all have potential. So does support in developing the necessary skills in time management finance or leadership to be an effective doctor-manager. Initiatives such as the Point of Care Foundation's Schwartz Rounds, ${ }^{10}$ designed to help doctors reflect on difficult clinical situations, are welcome, as are sabbaticals or protected time for development activity.

Right now, doctors in the NHS face workforce gaps, inexorably rising demand, and struggling community care services. ${ }^{11}{ }^{12}$ They're working in a system on the edge, compounded by top-down target pressures and serial, politicised reorganisations. In the recent industrial relations dispute with junior doctors the health secretary deployed the combative language of blame and shame, and some sections of the mainstream media added to the mood music. ${ }^{13}$

It's an understandable impulse to give reassuring platitudes and shift responsibility for wellbeing onto individual practitioners. But a resilient system is what we need: one that adequately recruits, retains, values, and supports its employees.

Competing interests: See www.bmj.com/about-bmj/freelancecontributors/david-oliver.

Provenance and peer review: Commissioned; not externally peer reviewed.

Follow David on Twitter: @mancunianmedic

Oxford English Dictionary. Definition: resilience. https://en.oxforddictionaries.com/definition/ resilience.

2 Health Education England. Definition: resilience. https://hee.nhs.uk/hee-your-area/wessex/ education-training/doctors/keep-calm-workshop/resilience.

3 National Health Executive. GMC to offer "emotional resilience" training for doctors under investigation. 23 Dec 2014. www.nationalhealthexecutive.com/Workforce-and-Training/ Page-27/gmc-to-offer-emotional-resilience-training-for-doctors-under-investigation.

4 Lind S. New GMC guidance expects medical students to build "resilience."[article]. Pulse 2016;358. www.pulsetoday.co.uk/your-practice/regulation/new-gmc-guidance-expectsmedical-students-to-build-resilience/20031953.article.

5 Lemaire JB, Wallace JE. Burnout among doctors. BMJ 2017;358:j3360. doi:10.1136/bmj. j3360 pmid:28710272.

6 Smith F, Goldacre MJ, Lambert TW. Adverse effects on health and wellbeing of working as a doctor: views of the UK medical graduates of 1974 and 1977 surveyed in 2014. JR Soc Med 2017;358:198-207. doi:10.1177/0141076817697489 pmid:28504070.

7 Royal College of Physicians. Being a junior doctor. 1 Dec 2016. https://www.rcplondon. ac.uk/guidelines-policy/being-junior-doctor.

8 Oliver D. David Oliver: Older doctors revisited. BMJ 2017;358:j17. doi:10.1136/bmj. j17 pmid:28087498.

9 lacobucci G. NHS unveils service to help GPs with burnout. BMJ Careers 7 Oct 2016. http://careers.bmj.com/careers/advice/NHS_unveils_service_to_help_GPs_with_burnout.

10 Point of Care Foundation. Schwartz Rounds. https://www.pointofcarefoundation.org.uk/ our-work/schwartz-rounds/. 
11 Royal College of Physicians. Underfunded, underdoctored, overstretched: the NHS in 2016. 21 Sept 2016. https://www.rcplondon.ac.uk/guidelines-policy/underfundedunderdoctored-overstretched-nhs-2016.

12 Royal College of Physicians. NHS reality check: delivering care under pressure. 16 March 2017. https://www.rcplondon.ac.uk/projects/outputs/nhs-reality-check-delivering-careunder-pressure.
13 Clarke R. Your life in my hands. John Blake Publishing, 2017. https://bookshop. theguardian.com/your-life-in-my-hands.html.

Published by the BMJ Publishing Group Limited. For permission to use (where not already granted under a licence) please go to http://group.bmj.com/group/rights-licensing/ permissions 